\title{
Towards a Rancièrean Critical Theory
}

\section{Matthew Lampert}

Journal of French and Francophone Philosophy - Revue de la philosophie française et de langue française, Vol XXVII, No 2 (2019) pp 95-126

\author{
Vol XXVII, No 2 (2019) \\ ISSN 1936-6280 (print) \\ ISSN 2155-1162 (online) \\ DOI $10.5195 /$ jffp.2019.891 \\ www.jffp.org
}

\section{(c) BY-NC-ND}

This work is licensed under a Creative Commons Attribution-Noncommercial-No Derivative Works 3.0 United States License.

\section{ULIS D-Sunt}

This journal is operated by the University Library System of the University of Pittsburgh as part of its D-Scribe Digital Publishing Program, and is co-sponsored by the University of Pittsburgh Press 


\title{
Towards a Rancièrean Critical Theory
}

\author{
Matthew Lampert \\ Northeast Texas Community College
}

In her introduction to Recognition or Disagreement, Katia Genel writes that the work of Jacques Rancière and the various authors of the Frankfurt School can all be called "critical theory," as long as "we consider the appellation 'critical theory' in a very broad sense." 1 In this very broad sense, "critical theory ... operates by mobilizing concepts and methods ... in order to call into question the relationship between knowledge or discourse and power. In this sense, criticism has also been understood as a diagnosis of the present and an engaged practice rather than as a mere theory."2 Jean-Philippe Deranty sketches critical theory in similarly broad terms in order to bring Rancière and the Frankfurt School under the same umbrella. For Deranty, this broad category of critical theory is a "style of 'philosophical critique," one which "draws from the empirical realities of social and historical developments" in order "to provide analytical tools to articulate the criticism of some of these social developments." 3 Genel and Deranty both refer to this broadest category of critical theory as a "style" or "styles" 4 of "critical thinking" that emerged in both the United States and Europe over the second half of the twentieth century; this large tent includes "French Theory," feminism and gender studies, critical race theory and postcolonial studies, and various strains of (neo-, post-, etc.) Marxism - the Frankfurt School of course included.

While it seems clear to everyone that Rancière's work can be described as critical theory in the broadest sense, 5 critical theory in its original and more widely-recognized sense is restricted to work within the "Frankfurt School" (Institut für Sozialforschung) tradition.6 Even within this narrower, institutional designation, however, critical theory serves as more than just a label indicating place of origin. Rather, critical theory in the Frankfurt School tradition is selfconsciously distinguished from other, "non-critical" types of theory. And so, 
while Jacques Rancière has never been affiliated with the Institut für Sozialforschung in any way, I want to consider the extent to which his work can be described as critical theory in this narrower sense, as a project fitting the criteria laid out by the Frankfurt School to describe their own work. I will argue that Rancière's work is not critical theory in this narrower sense. My argument, however, will allow me the opportunity to do two things. First, it will give me a chance to subject the narrower project of critical theory to a kind of Rancièrean analysis: to read the project of critical theory through the lens of Rancière's work, identifying the points where his work not only fails to meet the Frankfurt School criteria, but actually rejects or criticizes that very project. Second, I will lay out what I take to be a version of critical theory which survives such Rancièrean criticism, and in turn I will consider at the end of this essay what a Rancièrean critical theory might entail. I will finish with a brief indication as to why I think such a project is worth pursuing.

In what follows, I will primarily identify critical theory with the projects pursued by the first and second generations of the Frankfurt School. I recognize that the designation has been given a number of different reworkings even within the Frankfurt School tradition, and that the term is less a pre-given category than it is an ongoing conversation. It will not be my intention to suggest that the version of critical theory I present here is the only (or even most authentic) version, nor will I argue that all versions of Frankfurt School critical theory can be subjected to the same Rancièrean criticisms that I address in this essay. Rather, I am attempting to identify a few more-or-less canonical interpretations of critical theory as a way of opening up what I take to be an interesting area of conversation between Rancière and the Frankfurt School tradition. In the first section, therefore, I will identify what I take to be the key criteria by which Frankfurt School critical theory is to be distinguished from non-critical theories. Then, I will bring Rancière's work to bear upon these criteria, showing why I think he would be skeptical of the entire project of critical theory. In the final section, however, I will take up a revised version of the critical theory criteria, outlining a version of it that I think might survive Rancière's criticisms. I will argue that even by these criteria, Rancière's work cannot be regarded as a kind of critical theory, but I will offer several suggestions for a possible Rancièrean critical theory and try to show why I think such a project might be valuable.

\section{What Is Critical Theory?}

What does it mean to practice critical theory? In an early, programmatic statement, Horkheimer uses the term to differentiate his approach (and that of his colleagues) from "traditional theory." He distinguishes the content, focus, and logical structure of the two types of theory-which, in a postscript, Horkheimer calls "two ways of knowing."7 But he also calls critical theory a "critical attitude," motivated by a sense of the role played by theory in society, an awareness of the state of things, and an effort to resolve tensions and contradictions within the theorist's own life and practice. Following 
Horkheimer's comments and the practice of his Frankfurt School colleagues, we can distinguish critical theory from traditional theories along two major axes: method and intention. 8

\section{Method}

Robin Celikates identifies three major components to the methodological distinction between critical theory and non-critical theories: critical theory is self-reflexive, interdisciplinary, and materialist.9 The materialism of critical theory's method is, above all, its foundation in actual "social and political struggles and the oppositional experiences and forms of consciousness they express."10 On the one hand, critical theory's grounding in oppositional struggles distinguishes what Deranty calls "purely conceptual approaches from approaches that use the reference to real existing societies to develop their conceptual core." 11 This differentiates critical theories from other kinds of political philosophy, but-as the context of Deranty's own comments shows - it is not enough to distinguish critical theory (i.e., the kind practiced by the Frankfurt School and its adherents) from the critical theories of Althusser, Foucault, Judith Butler, etc. On the other hand, critical theory's materialism is not an entirely straightforward matter, such that any one narrow description of it could capture all (or even most) of the Frankfurt School practitioners. Already in Horkheimer's essay the "critical" function of critical theory is turned also upon the forms of consciousness expressed by oppositional forces. "If critical theory consisted essentially in formulations of the feelings and ideas of one class at any given moment," writes Horkheimer, "it would not be structurally different from the special branches of science." There is thus "the ever present possibility of tension between the theoretician and the class which his thinking is to serve," and the theorist must practice "an aggressive critique not only against the conscious defenders of the status quo but also against distracting, conformist, or utopian tendencies within his own household."12 In Nancy Fraser's words, "critical theory frames its research program ... with an eye to the aims and activities of those oppositional social movements with which it has a partisan, though not uncritical, identification." 13 The question of exactly how critical theory is rooted in these oppositional movements is a matter of extensive debate within the Frankfurt School tradition. As Robin Celikates notes, the Frankfurt School found it progressively harder over the last decades of the twentieth century "to identify 'struggles of oppressed groups' which could serve as their point of reference in practice. . . . As is well-known, in response to the paradoxes, or dead-ends . . later generations of the Frankfurt School, especially Jürgen Habermas and Axel Honneth, turned to developing more openly normative programs" of critical theory. 14

Critical theory's materialism is thus necessary for distinguishing it from the kinds of abstract, conceptual political philosophy mentioned by Deranty. However, no particular version of this materialism seems to characterize the full tradition of the Frankfurt School, much less to distinguish critical theory (in 
the narrow sense) from other critical theories (in the broader sense). We must look to the other criteria listed by Celikates to help us distinguish Frankfurt School-style critical theory from its critical cousins.

The self-reflexive criterion means that a genuinely critical theory must take "into account the social and historical conditions of theory formation, including its own." 15 Methodologically, traditional theory maintains a strict split between the knowing subject (the scientist or theorist) and his object of study, between thinking and acting, and between academic activity and the social context in which it takes place. In traditional theory, the world is taken as "given," and understanding and perception are conceived of as active and passive, respectively. This is an understanding of theory, as Horkheimer notes, generated by the practice of the modern, physical sciences-and, more importantly, the social context in which they are embedded. Early on in his essay, Horkheimer turns his critical eye on the "sciences of man and society" that have "attempted to follow the lead of the natural sciences." 16 Despite the many differences between various schools of sociology, Horkheimer says that they all "have an identical conception of theory and that it is the same as theory in the natural sciences." 17 This is, he explains, an ideological error engendered by the social role of the academic researcher in the modern era, and so even where some of its methods can be useful, "traditional" social theory is itself in this regard founded on a mistake. Critical theory is-in at least one sense18-true, where traditional theory is in error.

Anticipating much work (and drawing on still more) within the sociology of knowledge and the philosophy of science, Horkheimer argues the specific form and development of any particular science is largely shaped by social forces external to that science, at least as the science is modeled within the traditional approach. The "directions and goals of research," Horkheimer writes, "are not self-explanatory nor are they, in the last analysis, a matter of insight." 19 Instead, scientific research is shaped by socioeconomic forces. As it goes for particular scientific inquiries, so too it goes for science as such: Modern science restricts itself to dealing in facts, but this is simply to say that the legitimation of science as such is something that happens outside of the practice of science. The narrow view of the scientist, whose activity "takes place alongside all the other activities of a society but in no immediately clear connection to them," thus easily gives rise to the illusion that science is an interest-free or "value-neutral" undertaking.20 Scholarship is never valueneutral. The taking up of one or another line of inquiry always presupposes some guiding interest, and these interests are not politically neutral. Researchers who labor under the illusion that their work is value-neutral thus succumb to an ideological error. To realize that this is not the case, Horkheimer seems to suggest, is to develop what he calls a "critical attitude." 21 Such a critical attitude will not change the role assigned to science by modern society-but a scholar with a critical attitude must then immediately become aware of the tensions and contradictions that structure his or her own 
practice.22 Thus-as we shall say below-critical theory's methodological criteria are inextricably linked with its intentions. But the important point here is that the myopic view of the traditional theorist also leads him to misunderstand his own practice. Thus, the limitations of traditional theory and the social sciences must be overcome by critical theory's methods.

While Horkheimer and Rancière are both highly critical of the social sciences, their specific criticisms are very different. For Horkheimer, these "sciences of man" are not politically suspect so much as they are simply methodologically underdeveloped (too un-self-reflective). As Karin Stögner puts it, "empirical findings were regarded as merely pre-scientific" for critical theory, "they needed to be considered in a more reasonable theoretical context. Thus, empirical social research was rather given the status of an auxiliary discipline."23 The point, for Horkheimer, is therefore not to undo the sciences of man, but rather to bring them together-under philosophywithin a unified, self-reflexive research project aimed at understanding (and changing) the world. It is in this sense that critical theory's interdisciplinarity is a rejection of "any desire for philosophical purity," integrating "philosophical analysis with social theory and empirical social research."24 Horkheimer's vision for an interdisciplinary critical theory is laid out very early on, in his inaugural lecture as rector of the Institute for Social Research:

Today .. . all depends on organizing research around current philosophical problematics which, in turn, philosophers, sociologists, political economists, historians, and psychologists engage by joining enduring research groups in order to do together what in other areas one is able to do alone in the laboratory and what all true scientists have always done: namely, to pursue their philosophical questions directed at the big picture with the finest scientific methods, to transform and make more precise these questions as the work progresses, to find new methods, and yet never lose sight of the whole. ... This approach to the science of society cannot be mastered by one person alone-given the vast subject matter as well as the variety of indispensable scientific methods whose assistance is called for. 25

I will have more to say in the next section about how Rancière might view critical theory's use of empirical social research; but for now, let us note that critical theory's interdisciplinarity is not the same as Rancière's "indisciplinarity." As Rancière himself has described it, indisciplinarity "is not a matter of going besides the disciplines but of breaking them." Rancière seeks not simply to reject "philosophical purity" and work "between" the disciplines, but to undo the disciplines-to "question . . . the distribution of territories, which is always a way of deciding who is qualified to speak about what." 26 Oversimplifying things a little, we might say that the Frankfurt School uses an interdisciplinary approach in order to seek a fuller mastery of their subject, 
while Rancière's indisciplinary approach seeks to question and undermine this very mastery.

To distinguish methodologically between critical theory and other critical theories, following Horkheimer, we must look at the ways in which knowledge is being generated. Critical theory attempts to overcome false knowledgeboth (primarily) the false knowledge of ideology and the limited, prescientific knowledge generated by the sciences. The methodological construction of critical theory's knowledge is therefore simultaneously a story about how others-both the masses and other theoreticians-do not know. Critical theory is taken up in an effort to "get things right," but this is also presented as a qualification for being able to engage in correct praxis. Before we turn to Rancière's criticisms of this approach, however, we have to connect this methodological claim with the other criterion by which critical theory is separated from non-critical theory: its intentions.

\section{Intentions}

With respect to its intentions, critical theory is distinguished in Horkheimer's work by a belief that the world is not as it should be. Traditional theory is descriptive, anchored in observation of the way the world is, while critical theory is an inherently normative enterprise, starting from a conception of the way the world ought to be (or, perhaps more accurately, from a critical rejection of-or protest against-the way the world is). As Celikates puts it, critical theory must be "emancipatory, i.e. guided by the goal of social emancipation ... whose possibilities it seeks to expand in connection with political and social movements." 27 Stögner, for her part, goes so far as to call the emancipatory intention "the major difference" between critical theory and traditional theory. "Horkheimer grounded Critical Theory on a motivational foundation and practical intention that aim to bring an end to avoidable suffering." 28 Traditional theory is marked by an empirical concern with observable facts and the attempt to understand the world as it is given. Critical theory, beginning with a conception of the world as a (social) process and result, is marked by an action-guiding concern with changing the world. This is the approach that will be picked up by Habermas in Knowledge and Human Interests. Traditional theory - that is to say, empirical science-is motivated by an interest in control, while critical theory is motivated by an interest in emancipation.29

Horkheimer's use of the term "critical" thus carries two meanings. In separating out a true conception of theory from one founded upon an error, critical theory is critical in the rationalist sense of the term: it serves to separate truth from error or falsity. But Horkheimer's critical theory is also critical in the sense that it is normative, driven by a picture of the way the world ought to be-an interest in "emancipation" or "human flourishing." Far from thinking that these two uses of critical are in tension or at war, however, we should see how they are specifically linked: to take up the correct view of theory is to add 
a self-reflective element to theoretical activity. Such an element cannot but call the theorist's attention to the tensions at work both within her practice, and between her practice and the rest of her life.

Horkheimer tells us that critical theory is therefore (also?) an attitude. This is to place it on the side of the individual researcher, who either takes up this attitude or does not. By taking up this attitude, the researcher takes not some external, given object as his or her focus of study, but "society itself" that is to say, the society of which the theorist is also a part. 30 However, society is taken up, not so that the theory might aid the "better functioning" of any particular part (one way of understanding the role of a "critic"31), but rather with an eye to the ways in which the organization of society sets the individual against himself, or positions him in conditions of unfreedom. The theorist's study of society is marked by a tension: society must be taken as it actually is in order for it to be studied (anything else would be "pure idealism"). The given society-and even our ways of understanding society-must be regarded as a social product (in other words, not an inevitable state of affairs) and "condemned." 32 With the formal definition of critical theory sketched out, Horkheimer turns over the course of the second half of his essay to address the purpose and function of critical theory. In a passage worth quoting at length, he writes:

The scholarly specialist "as" scientist regards social reality and its products as extrinsic to him, and "as" citizen exercises his interest in them through political articles, membership in political parties or social service organizations, and participation in elections. But he does not unify these two activities, and his other activities as well, except, at best, by psychological interpretation. Critical thinking, on the contrary, is motivated today by the effort really to transcend the tension and to abolish the opposition between the individual's purposefulness, spontaneity, and rationality, and those work-process relationships on which society is built. Critical thought has a concept of man as in conflict with himself until this opposition is removed. If activity governed by reason is proper to man, then existent social practice, which forms the individual's life down to its least details, is inhuman, and this inhumanity affects everything that goes on in the society. 33

What does it mean to say that critical thinking is "motivated . . . by the effort ... to transcend the tension and abolish the opposition" laid out above? Such an effort cannot simply be the taking up of a critical attitude, for this is exactly the sort of psychological interpretation attempted by certain scholarly specialists. Instead, this tension or opposition is rooted in the very inhumanity of society itself. As such, an effort to transcend the tension and opposition discovered by critical theory must take place through an engagement with society. Critical theory is not what resolves the inhumanity of society, but is instead taken up as part of the effort to overcome this inhumanity. 
What does it mean, however, to say that critical theory is part of the effort to overcome the inhumanity of society? One major way of cashing out this claim would be to answer that writing critical essays is itself a form of struggle. But in what sense can writing a critical essay be seen as a form of political struggle? Critical Theory's answer to this question seems to be tied to two key practices: Ideologiekritik and normative clarification.

\section{The Project of Critical Theory}

In The Idea of a Critical Theory, Raymond Geuss identifies several theses held by the members of the Frankfurt School:

1. That "the ultimate goal of all social research should be the elaboration of a critical theory of society of which Ideologiekritik would be an integral part."

2. That the critique of ideology is not a debate about values, but rather the identification of a form of consciousness as "false" or "a form of delusion"; Ideologiekritik, Geuss writes, is thus "itself a cognitive enterprise, a form of knowledge." 34

Critical theory's self-reflexivity and interdisciplinarity are thus connected to its emancipatory aims in large part through the ways in which the former can help it identify and criticize ideological forms of consciousness. Critical theory's emancipatory aims are thus first of all directed against a revolution that should have taken place but didn't. "Philosophy . . . lives on because the moment to realize it was missed. . . . [T] he attempt to change the world miscarried." 35 Early Frankfurt School sociological studies of mass psychology, totalitarian propaganda, and the authoritarian personality are all projects to this same end.

No mere sniping or descriptive analysis, however, critical theory's Ideologiekritik is part of an action-orienting analysis of society. Along with stripping away the seeming obviousness of certain (false) ways of understanding the world, it is critical theory's job to identify tensions within society that might be exploited in the struggle to change the world. "The point of this," writes Stögner, "is to trace and reveal very real social conflicts as well as the potential for a social change they might contain." $36 \mathrm{~A}$ major aim of critical theory is to be appropriated by the agents of change. It is this actionguiding purpose which sets critical theory apart from non-critical (and traditional) theories. Interdisciplinarity and self-reflexivity allow critical theory to develop a correct picture of the world. Critical theory then aims to lead those suffering from false consciousness to reflect (and self-reflect), helping to spur (and guide) their revolutionary action. Raymond Geuss therefore links critical theory's action-orienting component with Ideologiekritik. Critical theories "are aimed at producing enlightenment in the agents who hold them; i.e., enabling those agents to determine what their true interests are," and they are "inherently emancipatory, i.e. they free agents from a kind of coercion 
which is at least partly self-imposed, from self-frustration of human action." 37 In the absence of an actual revolution-or in the place of one that never happened-critical theory's purpose is "safeguarding the link between theory and (the possibility of a radically different) practice." 38 This is why Horkheimer ends his "Traditional and Critical Theory" article with the observation that "the truth may reside with numerically small groups of men," who, "hardly noticed even by those opposed to the status quo, outlawed but imperturbable, may at the decisive moment become its leaders because of their deeper insight." 39

Beginning with Habermas, as is well known, critical theory takes on a more explicitly normative aspect. But Habermas's own communicative turn is of course still a version of Ideologiekritik. Celikates notes that in Habermas it is still "one of the main tasks" of critical theory "to analyze and bring to the agents' attention the distortions that block them from addressing and overcoming obstacles to emancipation." 40 Habermas's attempts to set critical theory upon new normative foundations, however, adds a new line of debate within critical theory (and between critical theorists). This has had, I believe, a twofold effect on the project of critical theory. On the one hand, it has diminished the extent to which the project of critical theory relies upon the other "sciences of man." The normative debates within critical theory are more philosophical and less sociological/economic/psychological than Horkheimer's early model had demanded. Second, this has brought critical theory much closer to other political theories, and especially to other critical theories. It is in this sense that Nancy Fraser, quoting Karl Marx, can summarize critical theory as "the self-clarification of the struggles and wishes of the age." 41 And yet, any attempt to distinguish critical theory from other critical theories must still return to the interconnection between the two criteria we've been discussing. Critical theory is distinguished from other critical theories by its method (a scientific method that provides a basis for Ideologiekritik) and its intentions (linking theory with emancipation through action-guiding reflection). Thus, Axel Honneth (head of the current Frankfurt School) will say that critical theory "is nothing but the continuation, by means of a controlled scientific methodology, of the cognitive labor that oppressed groups have to perform in their everyday struggles when they work to denaturalize hegemonic patterns of interpretation and expose the interests by which these are motivated." 42

\section{Rancière's Lesson}

If Frankfurt critical theory can be distinguished from other critical theories by an empirical, interdisciplinary method, self-reflexivity, and an actionguiding intention rooted in Ideologiekritik and a goal of emancipation, then it seems clear to me that Jacques Rancière cannot be called a critical theorist. Rancière's "indisciplinary" approach seeks to undermine the very disciplines upon which critical theory draws, and he has consistently eschewed normative claims, action-guiding analyses, and (especially) Ideologiekritik. More importantly, however, Rancière's work presents several challenges to the very 
project of critical theory. In his critical exchange with Axel Honneth, of course, several points of disagreement were already raised. Building upon these, however, in this section I want to gather together a handful of Rancièrean ideas that most centrally challenge the project of critical theory.

In Rancière's work, I think, we can identify three major objections to the project of critical theory:

1. Critical theory's claim to scientificity-grounded in its interdisciplinary method-is the creation and justification of the authority of the critical theorist. Thus, the "emancipation" offered by the critical theorist can only be the reassertion of a kind of domination.

2. Critical theory's sociological analysis of domination is ultimately a justification of that domination-especially in the area of Ideologiekritik.

3. Critical theory is ultimately an attempt to eliminate or suppress real equality in the name of an ideal, imaginary equality.

I shall take up each of these points one at a time, but it should be noted up front that they are absolutely interconnected.

\section{Critical Theory as a Rigorous Science}

Rancière's first major critical breakthrough was his public break with Louis Althusser, articulated in the 1969 essay "On the Theory of Ideology," and then five years later in his first book, Althusser's Lesson. While Althusser was a generation younger than the founders of the Frankfurt School and developed a version of Western (or post-) Marxism very different from theirs, there are also some striking similarities. Most interesting and relevant for our purposes is the way in which Althusser and Adorno both found themselves suddenly on the wrong side of the student movement of the late 1960s, defending academic privilege in the face of their own radical former students. Albeit rooted in different theoretical justifications, both Althusser and Adorno attempted to reassert academic hierarchies when pressed by students for a democratic reorganization of university life. As James Gordon Finlayson reports, "Adorno was . . . adamant that the teacher pupil relation was intrinsically asymmetrical and thus that universities could not be run entirely democratically." 43 Althusser makes very much the same claim in his essay "Student Problems," published in 1964. It was Althusser's justification of academic hierarchy that provoked Rancière's criticism, and several key points of that critique seem applicable to the project of critical theory.

In "On the Theory of Ideology," Rancière takes critical aim at the theoretical development of science as a weapon of revolutionary struggle. The first move in this development is to make science and ideology into opposites. Ideology becomes the "Other" of science. This is problematic in that it reduces 
all ideology to the dominant ideology. Struggle within ideology is dismissed, and ideology becomes unified and overarching-one thinks of Dialectic of Enlightenment and its diagnosis of all of Western thought as a totalizing system of ideology, for example, with myth and modernism as flip sides of the same coin. Adorno will of course eventually give up the attempt to put forward a positive science to challenge ideology, taking up a "negative dialectics" instead-but critical theory consistently pursues theory as an Other of ideology as a whole. There are two important consequences of this science/ideology split. The first is that it denies actual, ongoing class struggle in the domain of ideology. "Real" class struggle is dismissed as illusory. Second, once real class struggle has been done away with, the critical theorist reinvents it within theory; as the Other of ideology, the pursuit, development, and dissemination of science are taken to be ipso facto revolutionary. In this way, "ideology" is no longer the terrain of struggle, but is instead one of the positions within struggle. Opposing it is science, and those who develop and wield that science are thereby guaranteed their place on the progressive side of things. "The class struggle in ideology, forgotten at the start, reappears in a chimerical, fetishized form as a class struggle between ideology (weapon of the dominant class) and science (weapon of the dominated class)." 44 But why does the theorist reinvent the class struggle within theory? So that he can avoid dealing with it in reality:

Thus, insofar ... as he does not participate materially in the class struggle, he can only unite with the interests of the proletariat in a mythical fashion, by making the revolutionary objective coincide with that ideal point in striving towards which he justifies his own practice as a petty-bourgeois intellectual: the Ideal of Science. In other words, he adopts the "position of the proletariat" at the level of the denegation of his own class practice. 45

Were class struggle within ideology to be taken up, the theorist's own privilege as an academic would have to be examined; and so he transposes the class struggle into theory, in order to shift the emphasis away from the theorist.

This line of criticism may have been decisive against "Althusserianism" (Althusser himself even seems to have thought it was sound), but does it apply to critical theory? I have already quoted Horkheimer's problematic statement that "the truth may reside with numerically small groups of men," who "at the decisive moment become the leaders" of the revolution. Such passages seem to present the development of critical theory-pursued on the sidelines in order to "safeguard the link between theory and practice"-as revolutionary. We have seen that the emancipatory aspect of critical theory is foremost in its use as a weapon against ideology. And yet there appears to be a tension within Horkheimer's essay between such passages and others in which Horkheimer seems to have a different relation between intellectuals and activists in mind. "Critical theory is neither 'deeply rooted' like totalitarian propaganda nor 'detached' like the liberalist intelligentsia," he declares at one point.46 If critical 
theory is not like fascist propaganda, then Horkheimer would seem to be suggesting that it is not the critical theorist's role to make others care about things they don't currently care about (e.g., through convincing them that their "real interests" lie elsewhere). And if critical theory is not a matter of "detached" liberal intelligentsia, then he would also seem to be suggesting that it is not the critical theorist's role to detach from political struggle to comment upon it "as a man of learning addressing the entire reading public." Furthermore, Horkheimer writes that it is "the task of the critical theoretician to reduce the tension between his own insight and the oppressed humanity in whose service he thinks." 47 While this sentence appears to signal a separation between the theorist and the oppressed-such that one can be the servant of the other-it is, in fact, the lead-in sentence to a paragraph in which Horkheimer will lay out polemically the bourgeois idea of the intelligentsia as "detach[ed] from all classes ... a sort of sign of superiority of which it is proud." The fact that Horkheimer's critical theory rejects such a notion would suggest that talk of the critical theorist as the "servant" of the oppressed is neither cynical elitism nor the sign of a strict separation. The same paragraph ends with a swipe at the bourgeois "division of labor . . . between men who in social conflicts affect the course of history and the social theoreticians who assign them their standpoint." These lines do not completely push out other instances in which Horkheimer will write as if the critical theorists are an elite vanguard waiting in the wings to lead the revolution. However, the tension between these two standpoints should at least show us that there are resources within Horkheimer's program for another possible conception of critical theory.48 I will return to this point below, in presenting a version of critical theory which might hold up against Rancière's criticisms.

From his early analysis of the science/ideology split, however, Rancière will develop his criticism along several different lines. His attack on the way this split was used to justify academic hierarchies and the asymmetrical teaching relationship will be further developed in The Ignorant Schoolmaster. Inasmuch as there are certain overlaps between Althusser's "Student Problems" and the positions taken by Adorno, Horkheimer, and even Habermas during the student movement, it would be instructive to reread this book of Rancière's in conjunction with various Frankfurt School statements about pedagogy. However, I leave that matter to the side in order to focus on a line of development more relevant to our present discussion: Rancière's criticism of sociology, first developed through his reading of Pierre Bourdieu in the 1980s.

\section{Rancière Contra Sociology}

Beginning with The Philosopher and His Poor (1983), and then developing significantly within The Ignorant Schoolmaster (1987), Rancière begins to lay out what he calls his "method of equality." This method is developed first and foremost polemically, against a picture that should be familiar to readers of critical theory: 
Domination and exploitation, so the argument [goes], are the effects of a whole mechanism of social relationships. Those who suffer from them are made passive because they ignore the laws governing that mechanism. They must be taught how inequality works in order to know how they can change it. Of course, it is not enough to know it. The point is acting according to that knowledge, shifting from passivity to activity. But at this point, it appear[s] that the most difficult thing [is] to know what to do on the basis of that science, in what circumstances it [can] be turned into action and how that [can] be done. I was warned that those who rebelled against the law of domination did it wrongly most of the time: some of them because, as workers pinned down to their work place, they had no view of the global social structure; others because, as petit-bourgeois intellectuals, they had no concrete experience of class exploitation, and so on and so forth. 49

At work in this seemingly straightforward approach to critical social science is what Rancière calls a closed circuit or a perfect circle:

On the one hand, it said: people get pinned down to their place in the system of exploitation and oppression, because they don't know about the law of that exploitation or oppression. But on the other hand, it said: they don't know about it because the place where they are confined hinders them from seeing the structure that allots them that place.50

Or, more briefly still: "They are where they are because they don't know why they are where they are. And they don't know why they are where they are because they are where they are." This is the circuit linking Ideologiekritik with emancipatory social research, which is why Horkheimer says that today "all depends on" developing a new "science of society."

What does any of this have to do with a "method of equality"? The problem, for Rancière, lies at the very root of the undertaking, in the assumption that the oppressed need critical theory in order to liberate themselves. In Joseph Tanke's turn of phrase, critical theory refuses "prospects of auto-emancipation." "Workers are those who have no time for the labor of the dialectic; they thus require specialists dedicated to its cause. With such assumptions, ostensibly critical positions reaffirm the most traditional divisions of labor." 51 This is a method of inequality for two reasons. First, critical theory begins from the assumption that equality is something to be achieved (institutionalized), and that emancipation aims to produce such equality. Critical theory therefore begins with the assumption of inequality. Second, critical theory begins from a problem: The revolution did not take place. The proletariat, whose job it is to make the revolution, did not do its job. This failure to make the revolution must be explained-hence, the need for a theory of ideology. From these two assumptions of inequality derive the two 
major functions of critical theory: Ideologiekritik as a means of emancipation, and the scientific analysis of society as an action-guiding strategy for successfully implementing equality. But it is the axiom of inequality that motivates both of these functions: "sociological demystification is too simple: it starts from the premise of inequality, thereby discovering its traces everywhere." 52 Rancière will in fact make an even stronger claim: this assumption of inequality cannot help but itself reproduce that inequality.

Such is the objection at the heart of Rancière's rejection of sociology and so-called critical social research. This is a strong series of claims, but claims that can certainly be challenged. Alberto Toscano, for example, suggests that "though it may 'begin' from inequality (and how could it not . . .) it can also function as a sociology of equality, for instance in combining a meticulous, 'scientific' knowledge of cycles of production with the strategic capacity to interfere with them, and with the political will to make radically egalitarian wage demands." 53 There are two parts to this defense. First, the claim is that the inequality that sociology begins from is not the essential inequality of people-their incapacity — but rather the inequality of material circumstances (i.e., oppression, exploitation, domination). In other words, sociology need not assume that inequality is necessary in order to analyze contingent situations of hierarchy. Second, the claim is that sociology can be useful in political struggle, and that if we dismiss it as the theoretical reproduction of inequality, we reject one possible weapon in the effort to challenge injustice. "To think that explanation, strategy and knowledge, and indeed sociology itself, are not intrinsic components of politics is not only debilitating," writes Toscano, "it dispossesses ... those forced into positions of 'minority' of the very tools of emancipation." 54

In response to the first part of this defense, Rancière will argue that any analysis of inequality-no matter how couched in the language of contingency-must function in some way as a justification of that inequality, or else it will not explain anything. As Rancière will often put it, the $\mu \tilde{U} \theta o c$ is a $\lambda$ 'óoc (the story is also an argument) and contingency takes on some sort of necessary (or at least not-arbitrary) form.55 Beginning from inequality, and setting out to explain the persistence of inequality (in a way that makes rational sense), social research becomes "a science of the verification of inequality, a verification of the verification that is performed by those subjected to it. The verification of the verification makes it more radical since it transforms the arbitrary story into a scientific demonstration." 56 For Rancière, this scientific demonstration goes far beyond Plato's "noble lie," in that it seeks out the basis for the story in actual reality. "Plato makes inequality a 'story' that has to be believed in order to make inequality a reality. Modern social science makes inequality a reality and equality a goal to be reached from this starting point." 57 In Plato's Republic, Socrates and his interlocutors frame their noble lie as a story that would have to be taught to the workers in order to 
put them in their places. The Ideologiekritik of critical theory, by contrast, attempts to show why the workers cannot avoid already believing that story.

In its attempt to make the laws of inequality understood, social research therefore must make inequality real and, in some sense, rational. However, the second line of defense of social research would be to suggest that this approach is necessary (even if it is potentially politically problematic) in order to arm the oppressed with the scientific tools to effectively change their situation. And so, a rigorous defense of critical theory might go something like this: social science, bringing with it some problematic assumptions, is always in danger of simply begging the question (as Marx might say, it "assumes in the form of fact . . . what [it] is supposed to deduce" 58 ). However, the interdisciplinary method of critical theory is specifically intended to offset this. It places these prescientific results and theories at the disposal of philosophy, and the emancipatory intention of critical theory can therefore take them up and recontextualize them. In so doing, critical theory becomes not the science of oppression, but the science of emancipation-it becomes a science necessary for the emancipation of the oppressed. This defense, however, fails to really address Rancière's criticisms. For even at the metatheory level, critical theory is still driven by the goal of assisting in the emancipation of those unable to emancipate themselves. It is, in the end, still a story about why the oppressed need critical theory. In this respect, Robin Celikates's Critique as Social Practice is illuminating. Celikates rightly rejects the traditional selfconception of the sociologist as epistemologically superior to his or her subjects. However, he also rejects the "egalitarian" approaches of ethnomethodology and the sociology of critique, arguing that Ideologiekritik must remain "an essential element" of critical theory because existing social conditions "prevent agents from taking part in social practices of critique by obstructing the development or exercises of their reflexive capacities." 59

Even if we set aside the problematic claim that the oppressed are incapable of reflection and dispossessed of critical practices, however, Celikates's claim is a familiar one: that critical theory is an essential tool for oppositional struggles. "[T]he social obstacles to everyday practices of critique and the reflexive capacities employed in these practices can ultimately be revealed and fed back into the critique of agents only by an empirical analysis ... that is informed by social theory and conducted by the individual social sciences." 60 Let us, for a moment, completely accept this claim. Let us allow, at least for the sake of argument, that oppositional movements need-or even can make productive use of-empirical analyses of society that are both "informed by social theory" and "conducted by the individual social sciences." Rancière would not deny this point, but would instead reply that it is by no means limited to just the output of so-called critical theories. We might apply the same methodological insight to sociology that Bruno Bosteels discovers in Rancière's work on political philosophies: "actual forms of politics may always take back certain categories and paradoxes from political philosophy 
so as to put them to emancipatory uses."61 Emancipatory politics might make use of categories, analyses, and insights developed by the social sciences, regardless of whether or not these social sciences have been harnessed by critical theory. In this sense, there is no difference at all between critical and non-critical theories, or between critical and traditional theory. For that matter, Rancière has explicitly addressed the flip-side of this coin on numerous occasions: "there is no theory of subversion that cannot also serve the cause of oppression." 62 This is precisely the insight motivating Rancière's attack on sociology in the first place. The theories of Bourdieu and other "progressive" sociologists (not to mention the theories of Althusser and other "Marxist" philosophers) have been taken up by the forces of order, hierarchy, and domination. There is no method that can guarantee the liberatory use of a theory. There is only the contingent uses to which that theory is put. This contingency is ultimately maddening for the would-be critical theorist, as it denies critical theory any guaranteed (necessary) role in oppositional politics. Indeed, this will be Rancière's final criticism of critical theory: that in the end it is an attempt to impose order on politics, a process which is always-by its very nature-disordered.

\section{Politics Without Guarantees}

For Rancière, every order is a form of hierarchization and exclusion. Every form of "society" is a "distribution of the sensible," constituting the very terms in which debate and participation can happen. Each such order will excludemake invisible-certain agents, lives, and ways of being, those who "have no part." There can be no final, complete order of equality for Rancière; instead, equality is that pre-given which always threatens to erode or destroy any ordering of the social. Such ordering, as is well known, is what Rancière calls "the police"; "politics," then, is the messy, contingent activity of disrupting the police order, rooted in this very ineliminable equality and the paradoxical insistence of "those who have no part" that they have a rightful claim to an equal part. Rancière will therefore reject the very terms in which political

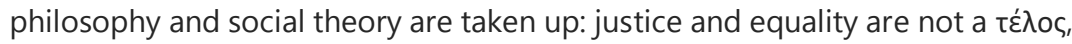
equality cannot be institutionalized, there is no ideal "rational society" that might normatively orient our political activity, and every politics of consensus is also necessarily a politics of exclusion. This is why, in Rancière's debate with Axel Honneth, the issue of teleology is raised. Starting with Habermas, the classically Marxist philosophy of history at work in the first generation of the Frankfurt School is rejected as metaphysically untenable. But for Rancière, such critiques do not go far enough, for there is still a metaphysically untenable philosophy of history at work in the normative framework of critical theory. "My problem with this," says Rancière, is that "we have to presuppose some kind of telos, an orientation toward the future, some kind of motor of history. From my point of view, there is no motor of history: history does nothing." By making "equality and not integrity the crucial concept and the motor of the political and subjective dynamic," Rancière is able to eliminate the problematic 
(both metaphysical and inegalitarian) teleological "motor" of history. It's a difficult claim for critical theory, but Rancière says that "it is the only way in which we can think equality, not as a kind of dream in the future, but as the power that is already at work in all our relations." 63

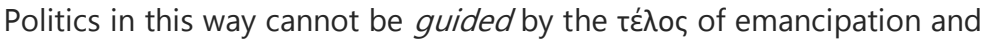
a rational society. Politics is not the attempt to bring rational order, but to overturn it! This will be the idea that sets Rancière against social theory, even (and especially?) of the critical kind. The attempt to link the philosophical ideal of order and rationality with the institution(s) of society cannot be a guide for politics, but must instead inevitably attempt to eliminate it. In Disagreementthe book in which he first explicitly lays out his distinctive account of politicsRancière identifies three models of what he calls (pejoratively) "political philosophy": archipolitics, parapolitics, and metapolitics. All political philosophies ("at least those worthy of the name," Rancière writes) "are philosophies that offer a solution to the paradox of the part of those who have no part, either by substituting an equivalent role for it, or by creating a simulacrum of it, by performing an imitation of politics in negating it." 64 The three figures of political philosophy are different "solutions" to the messy, irrational paradox of egalitarian politics. Each attempts, in its own particular way, to negate real politics in favor of some philosophical alternative. Each seeks to replace the irrational mess with a rational order. In the service of this order, Rancière shows how each figure of political philosophy has its own corresponding sociology. For archipolitics (which Rancière links with Plato's political philosophy), this is the sociology of unity and social cohesion, while for parapolitics (of which Aristotle is Rancière's primary example) it is the sociology of demographics and representation:

If Plato's archipolitics is transposed into the modern age into the sociology of the social bond and common beliefs correcting democracy's sloppiness and giving coherence to the republican body, parapolitics gleefully transforms itself into another brand of "sociology." ... Aristotle's [parapolitics] and its substitutes propose attainment of the idea of good through exact mimesis of the democratic discord blocking its attainment: the ultimate utopia of a sociologized politics, flipped over to its reverse, the serene end of politics whereby both sense of "end," as a telos fulfilling itself and as an eliminating gesture, come to coincide exactly.65

Metapolitics, on the other hand, Rancière discovers in the political philosophy of figures like Marx, for whom the "real" (rational) politics is a process happening "behind" or "underneath" the messy surface of empirical politics. Metapolitics, too, will have its own corresponding sociology. This sociology is the critical science of Ideologiekritik and the laws of history:

So metapolitics becomes the scientific accompaniment of politics, in which the reduction of political forms to the forces of the class 
struggle is initially equivalent to the truth of the lie or the truth of illusion. But it also becomes a "political" accompaniment of all forms of subjectification, which posits as its hidden "political" truth the class struggle it underestimates and cannot not underestimate. Metapolitics can seize on any phenomenon as a demonstration of the truth of its falseness. For the truth of falseness, Marx in his genius invented a word that all modernity has adopted, at times even turning it against him. He called it ideology.66

The attempt to discern the "laws of history" (and its motor) and the demonstration of the "truth of the lie" that is ideology are both, for Rancière, ways in which philosophy attempts to discover some true, orderly, rational politics behind the mess of worldly politics. But the attempt to master this real politics is the denial of really-real politics, and hence metapolitics "cannot not underestimate" the actual class struggle. "This also means that 'social science' ... has been in fact the very form of existence political philosophy has taken in the age of democratic and social revolutions. Social science has been the final form taken by ... the philosophical project of achieving politics by doing away with it." 67

As Bosteels puts it, "the success of the social sciences [as a whole] is in no small measure due to an ongoing desire to be done with the disorderliness of subjects who stubbornly refuse to stay in their assigned place and time or fail to stick to their prescribed task." 68 This, for Rancière, is why critical theory must deny the capacity of the oppressed to emancipate themselves. Autoemancipation is a messy, untimely, irrational affair. It doesn't create order, but disrupts it. It doesn't institutionalize equality, but overturns institutions. And it is not achieved by helping the oppressed to know their place (i.e., the job of the proletariat is to make the revolution), but rather when the oppressed refuse to know their place.

Earlier I had accepted-for the sake of argument-the idea that critical theory might be useful for oppositional political movements. In its softer form-merely claiming that critical theory is helpful, but not necessary - we saw that Rancière will undermine any distinction between critical and traditional theory as to its ability to be taken up by politics. In its firmer form, however-the claim that critical theory is necessary - we can now see that Rancière will insist that this "need" is ultimately driven by the attempt to negate politics: to take control of it and rationalize it, substituting an ideal, rational politics for the irrational politics it finds.

\section{Towards a Rancièrean Critical Theory}

Rancière is not a critical theorist. Furthermore, we can see from his work that he has numerous, fundamental problems with the very project of a critical theory. Finally, to the extent that Rancière is a critical theorist-that is, a thinker whose "style" of philosophical critique calls into question "the relationship between knowledge or discourse and power"-the object of his criticism is 
very different from the object of a critical theory. A critical theory is a critical theory of society. it "has society itself for its object," and "every part of the theory presupposes the critique of the existing order and the struggle against it along lines determined by the theory itself."69 The critical theorist may consider other theorists to have misunderstood the nature of their own practice (and therefore might consider the results of their science to be prescientific), but this is simply to approach other theorists the same way the critical theorist aproaches agents more generally. By contrast, Rancière is critical of other theorists. His target is not inequality in society, but rather the ways in which inequality has been theorized by sociologists, educators, artists, and philosophers. His target is rarely the conformist or the upholder of the status quo; he is far more likely to turn his critical faculties upon those who fancy themselves to be critical theorists!

Nevertheless, Rancière's criticisms of other theorists have been consistently leveled in the name of equality, and he is at every turn concerned with how we might better think about that equality. His work is certainly not in defense of the status quo, and the concepts he has developed are furthermore designed to undermine any justification of that status quo. Even where he has been critical of Marxism, critical sociology, critical theory, and other critical theorists, these criticisms have been launched from "the left" of their targets, always from a more radically egalitarian, oppositional position. All of which raises the question: Could there be a Rancièrean critical theory? Is there some version of a recognizably critical theory project that might persist after Rancière's criticisms and concerns have been addressed? What would a Rancièrean critical theory look like? To conclude this essay, I want to lay out several components of what I think such a project might entail. I will also try to indicate, as I sketch out these components, why I think that a Rancièrean critical theory might be worth pursuing — both within the context of Rancière's own work, and for those who are interested in pursuing such a project within the context of oppositional political movements. Having laid out Rancière's criticisms, I will take my cue from the various challenges for a Rancièrean critical theory raised above. This will provide us with a specific framework for developing the methodological and intentional aspects of a possible Rancièrean critical theory.

\section{A Process Without Goals?}

Beginning with the intentional aspects, it is clear that a Rancièrean critical theory cannot have as its intention the emancipation of the oppressed-and this for at least three reasons. First, in order to aim at emancipation, critical theory must deny in practice the agency of those it wishes to lead in theory. A Rancièrean critical theory cannot have as its goal the emancipation of those who are incapable of emancipating themselves. Second, such a critical theory

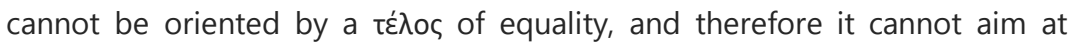


emancipation in the traditional sense. Finally-and perhaps most importantly-we must recall that for Rancière emancipation is an individual, aleatory process; it is separate from politics in the proper sense, even if the latter does in some way rely upon the former.

While the subject of politics for Rancière is always collective, emancipation is always an individual matter. It is a matter of "throwing off" one's assigned place, a process of desubjectivation. This desubjectivation throws one radically back upon oneself in a way that allows for the later formation of a collective political subject. But emancipation is still a separate moment, and there is no necessary, causal connection between the two events. To emancipate oneself is not ipso facto a political act. For Rancière, emancipation is above all intellectual emancipation, a process first addressed in Proletarian Nights. A central example, to which Rancière will return throughout his career, is that of the nineteenth-century "jobber," Gabriel Gauny, who is able to find aesthetic enjoyment even in the midst of menial toil. "Believing himself at home, he loves the arrangement of a room so long as he has not finished laying the floor. If the window opens out on a garden or commands a view of a picturesque horizon, he stops his arms a moment and glides in imagination toward the spacious view to enjoy it better than the possessors of the neighboring residences."70 Gauny is able to free himself to enjoy those pleasures denied to his class: aesthetic and philosophical contemplation. He throws off his worker-identity in these mental pursuits, "stealing" the life of an intellectual in between moments of toil. Rancière writes that Gauny "frees himself by becoming less aware of exploitation and pushing aside, thereby, its sensory grip. He frees himself by nurturing a power of selfdelusion."71 But Rancière is insistent that Gauny's "delusion" is not ideology. He knows full well that he is exploited, and he knows full well that he will die in poverty; "this 'illusion' is completely transparent. It is not unaware of anything about its causes or effects and seals no pact with the enemy it serves."72 Emancipation is a performance of equality, it subverts "a given distribution of the sensible."73 This "subversion" is not an overturning; it is merely an "illusion." But this illusion is transformative, "the illusion of emancipation is not a nonrecognition reproducing domination but the twisted path whose circle comes as close as possible to this reproduction but with an already crucial swerve or digression."74 The worker, having emancipated himself, is no longer the same man, "the emancipated worker cannot not be a rebel. The voluptuousness of emancipation is a fever from which one cannot be cured and which one cannot help but communicate." 75

Proletarian Nights is a series of narratives about the self-emancipation of workers. They do not need critical theory to emancipate themselves. But the book also introduces a figure who will become the central character of Rancière's following book, The Ignorant Schoolmaster. Joseph Jacotot. Jacotot's "universal teaching" is a pedagogy of auto-emancipation: the 
ignorant schoolmaster recognizes early on that students don't need masters. But for Rancière, Jacotot's true lesson is even more radical:

Universal teaching shouldn't be placed on the program of reformist parties, nor should intellectual emancipation be inscribed on the banners of sedition. Only a man can emancipate a man. Only an individual can be reasonable, and only with his own reason. . . . A professor is neither more nor less intelligent than another man, and he generally presents a great quantity of facts for the researcher's observation. But there is only one way to emancipate. And no party or government, no army, school, or institution, will ever emancipate a single person.76

The oppressed do not need critical theory to emancipate them. But more than this: critical theory cannot emancipate anybody, people can only do this for themselves.

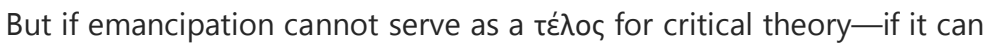
aim neither at the emancipation of the oppressed nor in the institution of equality in society-then what can its intentions be? Is there no proper basis, then, for Horkheimer's critical attitude, the orientation through which we might distinguish critical theory from its Other?

The most obvious answer to this question is that a Rancièrean critical theory's critical attitude will proceed from the method of equality; "all revolutionary thought must be founded on the ... presupposition ... of the capacity of the dominated." 77 The method of equality is a matter of verifying this equal capacity of all:

A verification of equality is an operation which grabs hold of the knot that ties equality to inequality. It handles the knot so as to tip the balance, to enforce the presupposition of equality tied up with the presupposition of inequality and increase its power. . . . That verification contributes, thus, to the framing of a new fabric of common experience or a new common sense, upon which new forms of political subjectivization can be implemented.78

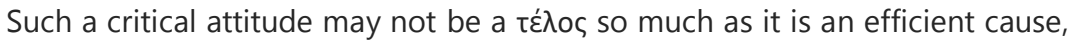
but it certainly differentiates a Rancièrean critical theory from non-critical (and non-Rancièrean) theory. A critical theory in this way will set out, not to diagnose inequality, but to verify equality. Its criticisms of society will not be the analysis of mechanisms blocking the self-reflection of the oppressed, but rather the unraveling of every "natural" hierarchy. "There is order in society because some people command and others obey," writes Rancière, "but in order to obey an order at least two things are required: you must understand the order and you must understand that you must obey it. And to do that, you must already be the equal of the person who is ordering you." There is no real 
basis for hierarchy, and a critical theory does not aim to establish or envision a justified order, but rather to eat away at every attempt at de jure justification.

Doubtless inferiors obey 99 percent of the time; it remains that the social order is reduced thereby to its ultimate contingency. In the final analysis, inequality is only possible through equality. 79

But beyond this foundational assumption of equality, there is another way we might distinguish a critical attitude for a Rancièrean critical theory. This is to return to two passages in Horkheimer that I quoted earlier:

Critical thinking . . . is motivated today by the effort really to transcend the tension and to abolish the opposition between the individual's purposefulness, spontaneity, and rationality, and those work-process relationships on which society is built. Critical thought has a concept of man as in conflict with himself until this opposition is removed. If activity governed by reason is proper to man, then existent social practice, which forms the individual's life down to its least details, is inhuman, and this inhumanity affects everything that goes on in the society. 80

It is the task of the critical theoretician to reduce the tension between his own insight and the oppressed humanity "in whose service he thinks." 81

Recall that Rancière had charged that "insofar . . . as he does not participate materially in the class struggle, [the critical theorist] can only unite with the interests of the proletariat in a mythical fashion, by making the revolutionary objective coincide with that ideal point in striving towards which he justifies his own practice as a petty-bourgeois intellectual." 82 This was a major motivation discovered behind critical theory: the defense of academic hierarchies and the denegation of academic privilege. But could not critical theory be driven to overcome this tension rather than hide it? Could this not be another way of making good on Horkheimer's claim? The intention or motivation of critical theory might be to reduce or overcome the tension between the critical theorist and the oppressed. Such a struggle would not be one of leading and liberating the oppressed, but rather of breaking out of the social place assigned to the privileged academic. (As Giuseppina Mecchia puts it, "intellectual endeavors are always profoundly disruptive of social assignations." 83 This may overstate the matter somewhat.) As part of a process of desubjectivation, this means that the aim of critical theory is emancipation after all. Although, it is not a matter of the critical theorist emancipating the oppressed, but of emancipating him- or herself, which is the only way that emancipation can work. This is what I have previously called "political" theory. However, as I argued in that earlier essay, the self-emancipation of intellectuals will take the form of a critical reflection on attempts to break with the material conditions constraining the role of the intellectual. The critical theorist must not speak for the marginalized, but from the margins. 84 
This latter conception of a Rancièrean critical theory, however, goes beyond what we find in Rancière's own work. While ultimately compatible, I believe, Rancière's work is not an attempt to overcome the tension between Rancière the academic and his audience. Rather, Rancière himself is strangely absent from his own works. This brings me to a second aspect of a possible Rancièrean critical theory: methodological self-reflexivity.

\section{Critical Self-Reflection}

Rancière's work certainly does not fall into the "philosophical error of positivism," that most prominent kind of traditional theory attacked by critical theory.85 Indeed, he is arguably further from positivism than the Frankfurt School is, given his "poetics of knowledge." Rancière aims ultimately to undercut all disciplinary distinctions, and treats all theory and knowledge construction as a series of stories.

All disciplines contend that they have their objects and the methods fitting them. The poetics of knowledge responds to this: your objects belong to everybody, your methods belong to anybody. They are made of narrations and descriptions that are told in a language that is the language of anybody. This also means that no positive boundary separates the texts that make up the discourse of science from those that are merely the objects of science. 86

But if Rancière's work could hardly be called traditional theory, this does not mean that it is self-reflexive in quite the way demanded by critical theory. As Horkheimer says, critical theory is not the work of an "isolated individual," but rather "a definite individual in his real relation to other individuals and groups, in his conflict with a particular class, and, finally, in the resultant web of relationships with the social totality and with nature."87 As Robin Celikates put it, critical theory "systematically takes into account the social and historical conditions of theory formation, including its own." 88

By contrast, the status of Rancière's own position as theorist is carefully absent from his work. Bruno Bosteels is not the first to raise "the thorny question of the exact status of Rancière's own discourse, in so far as he claims to avoid the trappings of 'political philosophy." 89 But as Bosteels goes on to show, there are places where the authority (whether claimed or not) of Rancière's work seems to require this self-effacement in problematic ways.90 Even as attention to this issue seems to potentially undercut-or destroy completely-Rancière's discourse, it also raises the question of what a possible reconstruction of that work might look like. What would it look like to turn the critical tools of Rancière's work away from other theorists and onto Rancière himself? What would it look like to take account of the position from which Rancière speaks as part of the construction of that theory? 
This self-reflexive element is at the heart of a possible Rancièrean critical theory. And such a critical theory, I think, has the potential to deepen Rancière's own existing work in powerful ways. As I have written elsewhere, 91 I think that such a self-reflexive element would have to begin by examining the place of the philosopher within the given distribution of the sensible. It would have to take into account the "ironic foundation" of Rancière's discourse, not in order to attack Rancière the philosopher, but in order to allow, as Rancière himself once put it, "the accent to be put on the ideological mechanisms of power which constrain the discourse of intellectuals in our societies."92 As we would expect from a critical theory, this self-reflexivity would be tied to the intention of emancipation, in just the terms I have laid out above. This would, finally, be to resituate Rancière's work within the activity described by Horkheimer: "His profession is the struggle of which his own thinking is a part and not something self-sufficient and separable from the struggle."93

\section{Social Research}

Even if we were to reimagine Rancière's work in self-reflexive terms, and to reimagine critical theory motivated by a method of equality instead of a

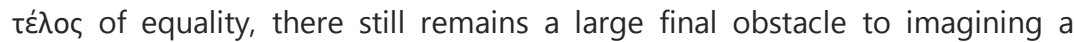
Rancièrean critical theory: the issue of sociological research. Given the centrality of social research to the project of critical theory, and given Rancière's staunch, withering criticism of sociology, it might seem that there can be neither compromise offered nor quarter given between them. But I believe that, if we pay closer attention to Rancière's objections, we might yet find an important place for social research within his work-albeit of a very different approach from the one it traditionally takes within critical theory.

Let me begin by noting that Rancière's own work has relied heavily upon a certain kind of social research-not on surveys conducted in the present, to be sure, but rather on surveys of the past. Nights of Labor, that work which first helped Rancière develop his own distinctive vision and voice, is built entirely upon the letters, articles, and other publications of nineteenth-century workers. While it is perhaps better called a work of history than sociology, Rancière's interest here is yet what the workers have to say about themselves, how they think about their lives and their world, and the relationships they build and keep. These are questions not so very distant at all from the ones a sociologist might ask of contemporary subjects of study, and I see no reason why one could not conduct in the present exactly the sort of study Rancière pursues in the past. The major difference between this and the sociology Rancière criticizes, of course, is in how it approaches its subjects. He does not examine worker discourse in order to diagnose it, nor is his intention simply to describe it-this is not simply "ethnomethodology" or the "sociology of critique." Rather, Rancière reads these discourses critically as a way of challenging theoretical constructions of "the working class." The work Rancière does in Proletarian Nights "challenges the literary and sociological canons of 
the best and most innovative recent social history. . . . He reads worker-run newspapers less for the programmatic statements they contain than for the contradictory and conflictual stories and letters that continually challenge the coherence of such statements." 94 This is, moreover, to say that Rancière draws upon social research in one of the essential ways demanded by critical theory: as evidence for the formation of better theory, the "correction of the deficiency in the situation of social philosophy." 95

If Rancière's thought is not essentially hostile to social research, however, we can also clearly see that the questions asked by that research are to be carefully chosen. As we have seen, one of the things Rancière faults critical theory for is the way its research is designed to reveal why oppression persists and why the revolution did not take place. Such research questions, starting with the presupposition of inequality, lead critical theory to verify inequality. The account critical theory gives of oppression-its structure and laws, how it reproduces itself, and why the oppressed do not overturn it-ends up rationalizing oppressions, justifying it: the $\mu \tilde{\theta} \theta$ os is a $\lambda$ óyoc. It is not that research into oppression should be forbidden! It is rather a matter of examining the assumptions and questions that guide research.

Rather than the empirical analysis of oppression, why shouldn't critical social theory look to analyze movements of resistance? Celikates returns us to the familiar logic of critical theory when he writes, "instead of asking why those who are 'oppressed, humiliated and disadvantaged' rebel in particular cases, we ought to ask why most of the time they not only tolerate the status quo but in fact contribute to its reproduction." 96 Rancière's work, by contrast, suggests that we ought to ask not only why the oppressed do rebel "in particular cases," but why we ought to study the forms those rebellions take, the self-understanding of the agents involved, and the strategies they adopt. We might approach contemporary oppositional groups the same way Rancière approached nineteenth-century Saint Simonians. We might ask, not "why do the oppressed sometimes rebel," but instead "why do they sometimes succeed?"

Furthermore, Rancière's work gives us, I think, a more powerful way to think about the terms in which we might find and study "success." Adorno's pessimism and the "Grand Hotel Abyss" of the early Frankfurt School derives from a conjunction between two ideas. First, as James Gordon Finlayson summarizes it, "Nothing short of a total social transformation of the whole society, a revolution in people's minds and actions, will do, because the very ways human beings have come to think and to act . . . are underlying causes of the existing oppression."97 But second, a revolution is also impossible. "Barricades are ridiculous against those who administer the bomb; that is why barricades are a game, and the lords of the manor let the gamesters go on playing for the time being." 98 Social research, then, proceeds from this starting point: "the practical contradiction in Adorno's theory," Finlayson says, "is simply the objective, if conflicted situation that Adorno's critical theory 
undertakes to explain; in a nutshell, that only a revolution will do, but no revolution is near."99

Rather than the all-or-nothing tragedy presented by traditional critical theory, Rancière's understanding of politics might lead us to look for very different kinds of "successes." Without the teleology of emancipation, critical theory can instead pay attention to disruptions, those fleeting moments of "politics" in Rancière's sense. It is true that every overturning of the distribution of the sensible eventually produces a redistribution of the sensible-that is, every politics eventually results in a new police. But if we are not looking for a once-and-for-all, eschatological solution, then we will not be so quick to dismiss such temporary suspensions as nothing. And if we are attentive to such disruptions when they happen, then we need not find ourselves asking why the revolution never happens.

That said, social research within a Rancièrean critical theory can also overcome some of the limitations of Rancière's own work in this area. As I have argued elsewhere, Rancière seems only concerned with successfu/disruptions of the distribution of the sensible, those leading to a new redistribution.100 A Rancièrean critical theory might look at both successful and failed attempts at politics. Furthermore, it might examine how those with "no part" make themselves "visible" or fail to do so. What makes some "illegitimate" claims successful (leading to a disruption), but others unsuccessful? How does the politics of visibility function?

\section{Conclusion}

Alain Badiou quips that, reading Rancière, "You will come to know what politics must not be, you will even know what it will have been and no longer is, but never what it is within the Real, and still less what one must do in order for it to exist." 101 This frustration-a common one for many of us as we read Rancière-stems mostly from the fact that Rancière's work asks what Paul Feyerabend calls "observer questions" about politics, rather than "participant questions." 102 This sideline perspective has been a shortcoming of certain strains of critical theory over the years as well, of course. But a self-reflective, egalitarian project of social research would go a long way towards overcoming this problem. A Rancièrean critical theory might critically resituate Rancière's own work, allowing us to ask important questions about what the role of the critic is, how politics happens, and what we might do to reduce the tensions between the former and the latter.

I have argued that Rancière himself is not a critical theorist. But while his project is highly circumspect about the very project of critical theory, I have tried to show that the two are not, in the end, mutually exclusive. I have laid out-in rough outline, at least-what I think a possible Rancièrean critical theory might look like. I have identified where I think it might productively build upon Rancière's own work, and how such a project might still (and better) meet some of the classic demands of a critical theory. In closing, 
however, allow me to note that even a Rancièrean project of critical theory would be unable to guarantee its own productive appropriation by oppositional movements. Such processes are above all aleatory, and the demand for guarantees of progressive credentials for theory must certainly strike us as an attempt to defend academic hierarchies. But there is at least one important struggle that such a project would certainly contribute to: As I have argued above, it is the project of the emancipation of intellectuals, the desubjectivation of the critical theorists themselves. Even if nothing else came of such a project, it seems to me that this would all on its own be a worthy cause.

1 Katia Genel, “Jacques Rancière and Axel Honneth: Two Critical Approaches to the Political," in Recognition or Disagreement: A Critical Encounter on the Politics of Freedom, Equality, and Identity, eds. Katia Genel and Jean-Philippe Deranty (New York: Columbia University Press, 2016), 6.

2 Genel, Recognition or Disagreement, 7-8.

3 Jean-Philippe Deranty, "Between Honneth and Rancière: Problems and Potentials of a Contemporary Critical Theory of Society," in Recognition or Disagreement: A Critical Encounter on the Politics of Freedom, Equality, and Identity, 35-36.

4 Deranty, "Between Honneth and Rancière," 7.

5 I myself have previously described Rancière's work in this way, writing that Rancière's "central concerns with oppression, revolutionary thought, and the capacity of the dominated mark his work quite clearly as critical political theory." See Matthew Lampert, “Jacques Rancière and the Politics of Theory," Cultural Critique 106 (Winter 2020): 1-26.

6 Cf. Martin Saar, "Critical Theory and Poststructuralism," in The Routledge Companion to the Frankfurt School, eds. Peter E. Gordon, Espen Hammer, and Axel Honneth (New York: Routledge, 2019), 323: “the term 'Critical Theory' . . . is first used as a reference in intellectual history with a clear demarcation (namely the Frankfurt School in its earlier phases, second, as a name for a group of diverse theories somewhat connected to the first two generations, and third, even broader, as the designation for a whole realm of critical social theory in its widest sense (with many poststructuralist works included)." 
7 Max Horkheimer, "Postscript," in Critical Theory: Selected Essays, trans. Matthew J. O'Connell (New York: Seabury Press, 1991), 244.

8 Max Horkheimer, "Traditional and Critical Theory," in Critical Theory: Selected Essays, 188-243.

9 Robin Celikates, "Critical Theory and the Unfinished Project of Mediating Theory and Practice," in The Routledge Companion to The Frankfurt School, 206; emphasis added.

10 Celikates, "Critical Theory," 206.

11 Deranty, "Between Honneth and Rancière," 35.

12 Horkheimer, "Traditional and Critical Theory," 214- 216.

13 Nancy Fraser, "What's Critical About Critical Theory? The Case of Habermas and Gender," New German Critique 35 (1985): 97; emphasis added.

14 Celikates, "Critical Theory," 208.

15 Celikates, "Critical Theory," 206.

16 Horkheimer, "Traditional and Critical Theory," 190.

17 Horkheimer, "Traditional and Critical Theory," 191.

18 For a helpful discussion of the sense(s) in which a normative social theory can be adjudged "true" or "false," see Raymond Geuss, The Idea of a Critical Theory: Habermas \& the Frankfurt School (Cambridge: Cambridge University Press, 1981), esp. pp. 75-95.

19 Horkheimer, "Traditional and Critical Theory," 195-196.

20 Horkheimer, "Traditional and Critical Theory," 197.

21 Horkheimer, "Traditional and Critical Theory," 207.

22 Horkheimer, "Traditional and Critical Theory," 209.

23 Karin Stögner, "Against the Reification of Theory and Praxis: On Critical Theory and Empirical Social Research," chap. 7 in Critical Theory and the Challenge of Praxis: Beyond Reification, ed. Stefano Giacchetti Ludovisis (Surrey: Ashgate, 2015), 85-86. 24 Celikates, “Critical Theory,” 206.

25 Max Horkheimer, "The State of Contemporary Social Philosophy and the Tasks of an Institute for Social Research," trans. Peter Wagner, in Critical Theory and Society: A Reader, eds. Stephen Eric Bronner and Douglas Mackay Kellner (New York: Routledge, 1989), 32.

26 Louis Baronian and M. Rosello, "Jacques Rancière and Indisciplinarity" (Interview with Jacques Rancière), trans. Gregory Elliot, Art \& Research 2, no. 1 (2008): 2-3.

27 Celikates, "Critical Theory," 206.

28 Stögner, "Against the Reification of Theory and Praxis," 87. 
29 Jürgen Habermas, "Knowledge and Human Interests: A General Perspective," appendix to Knowledge and Human Interests, trans. Jeremy J. Shapiro (Boston: Beacon Press, 1971): 301-317.

30 Habermas, "Knowledge and Human Interests," 206.

31 Horkheimer, "Traditional and Critical Theory," 207: "Although it itself emerges from the social structure, (Critical Theory's) purpose is not, either in its conscious intention or in its objective significance, the better functioning of any element in the structure."

32 Horkheimer, "Traditional and Critical Theory," 208.

33 Horkheimer, "Traditional and Critical Theory," 209-210.

34 Geuss, The Idea of a Critical Theory, 26.

35 T. W. Adorno, Negative Dialectics, trans. E. B. Ashton (New York: Continuum, 1973), 3. This line is also cited by James Gordon Finlayson to illustrate the same point; Finlayson writes, "For his part, Adorno had consistently maintained that one of the chief tasks of philosophy and social theory was to reflect on the fact that in the advanced Western nations no revolution had occurred." James Gordon Finlayson, "The Question of Praxis in Adorno's Critical Theory," in Critical Theory and the Challenge of Praxis: Beyond Reification, 62.

36 Stögner, "Against the Reification of Theory and Praxis," 89.

37 Geuss, The Idea of a Critical Theory, 2.

38 Celikates, "Critical Theory," 208.

39 Horkheimer, "Traditional and Critical Theory," 241.

40 Celikates, “Critical Theory,” 212.

41 Fraser, "What's Critical About Critical Theory?" 97; quoting Karl Marx, letter to A. Ruge, September 1843, in Karl Marx: Early Writings, trans. Rodney Livingstone and Gregor Benton (New York: Vintage Books, 1975), 209.

42 Axel Honneth, "Is There an Emancipatory Interest? An Attempt to Answer Critical Theory's Most Fundamental Question,” European Journal of Philosophy 25 (2017): 919; quoted in Celikates, “Critical Theory," 216.

43 James Gordon Finlayson, “The Question of Praxis in Adorno's Critical Theory,” 56, n. 16.

44 Jacques Rancière, "On the Theory of Ideology-Althusser's Politics," in Radical Philosophy Reader, eds. Roy Edgley and Richard Osborne (London: Verso, 1985), 108. 45 Rancière, "On the Theory of Ideology," 129.

46 Horkheimer, "Traditional and Critical Theory," 223-224.

47 Horkheimer, "Traditional and Critical Theory," 221; emphasis added. 
48 Even if two paths are available within Horkheimer's early work on critical theory, an examination of Horkheimer's later work would suggest that, despite a "radical" period extending into the early 1940s, his late career moved more often than not along the theoreticist path-with politically unfortunate results. Stephen Eric Bronner charges that Horkheimer's criticism of the student movement in the late 1960s significantly mirrors those of "a host of less philosophically talented mainstream conservatives." "Political conservatism became justified through philosophical radicalism," in Bronner's judgment, and "in keeping with his new prominence, [Horkheimer's] writings on returning to Germany generally adopted a decidedly cautious and anti-political tone." Rather than the critical reflections of one engaged in progressive struggle, Horkheimer's theory often takes up an elitist position outside of the struggle. Eric Stephen Bronner, Of Critical Theory and its Theorists (London: Blackwell, 1994), 89-90.

49 Jacques Rancière, "The Method of Equality: Propositions," in Genel and Deranty, Recognition or Disagreement, 133-134.

50 Rancière, "The Method of Equality: Propositions," 133-134.

51 Joseph J. Tanke, Jacques Rancière: An Introduction: Philosophy, Politics, Aesthetics (New York: Continuum, 2011), 31.

52 Tanke, Jacques Rancière, 32.

53 Alberto Toscano, “Anti-Sociology and Its Limits," in Reading Rancière, eds. Paul Bowman and Richard Stamp (New York: Continuum, 2011), 231.

54 Toscano, “Anti-Sociology and Its Limits,” 232.

55 See Jacques Rancière, "The Method of Equality: An Answer to Some Questions," in Jacques Rancière: History, Politics, Aesthetics, eds. Gabriel Rockhill and Philip Watts (Durham: Duke University Press, 2009), 276. "The logos is a muthos. The argument is a story, and the story an argument. The social distribution rests on that circle of the empirical and the prescriptive."

56 Rancière, "The Method of Equality: Propositions," 137.

57 Rancière, “The Method of Equality: Propositions," 137.

58 Karl Marx, "Economic and Philosophic Manuscripts of 1844," trans. Martin Milligan, in The Marx-Engels Reader, 2nd ed., ed. Robert C. Tucker (New York: W.W. Norton, 1978), 71.

59 Robin Celikates, Critique as Social Practice, trans. Naomi van Steenbergen (London: Rowman \& Littlefield, 2018), 10.

60 Celikates, Critique as Social Practice, 11; emphasis added. 
61 Bruno Bosteels, “Archipolitics, Parapolitics, Metapolitics," in Jacques Rancière: Key Concepts, ed. Jean-Philippe Deranty (Durham, UK: Acumen, 2010), 81.

62 Jacques Rancière, Althusser's Lesson, trans. Emiliano Battista (New York: Continuum, 2011), xvii.

63 Jacques Rancière, "Critical Questions on the Theory of Recognition," 94-95.

64 Jacques Rancière, Disagreement, trans. Julie Rose (Minneapolis: University of Minnesota Press, 1999), 65.

65 Rancière, Disagreement, 75.

66 Rancière, Disagreement, 85.

67 Rancière, Disagreement, 92.

68 Bosteels, "Archipolitics, Parapolitics, Metapolitics," 84.

69 Horkheimer, "Traditional and Critical Theory," 206, 229.

70 Gabriel Gauny, "Le travail à la tâche," quoted in Jacques Rancière, Proletarian Nights: The Worker's Dream in Nineteenth Century France, trans. John Drury (New York: Verso, 2012), 81.

71 Rancière, "The Method of Equality: An Answer to Some Questions," 277.

72 Rancière, Proletarian Nights, 81.

73 Rancière, “The Method of Equality: An Answer to Some Questions," 277.

74 Rancière, Proletarian Nights, 82.

75 Rancière, Proletarian Nights, 83.

76 Jacques Rancière, The Ignorant Schoolmaster: Five Lessons in Intellectual Emancipation, trans. Kristin Ross (Stanford: Stanford University Press, 1991), 102.

77 Rancière, Althusser's Lesson, xvi.

78 Rancière, "The Method of Equality: An Answer to Some Questions," 280.

79 Rancière, Disagreement, 16-17.

80 Horkheimer, "Traditional and Critical Theory,” 209-210.

81 Horkheimer, "Traditional and Critical Theory," 221; emphasis added.

82 Horkheimer, "Traditional and Critical Theory," 129.

83 Giuseppina Mecchia, "Philosophy and Its Poor: Rancière's Critique of Philosophy," in Jacques Rancière: Key Concepts, 42-43.

84 See Lampert, "Jacques Rancière and the Politics of Theory."

85 Critical theory, as Raymond Geuss puts it, is constructed "critically" against "the kind of philosophical error embodied in positivism" (where a "positivist" is "a person who holds (a) that an empiricist account of natural science is adequate, and (b) that all cognition must have the same cognitive structure as natural science"). The Idea of a Critical Theory, 2; emphasis added. 
86 Rancière, “The Method of Equality: Propositions," 150.

87 Horkheimer, "Traditional and Critical Theory," 210-211.

88 Celikates, "Critical Theory," 206.

89 Bosteels, "Archipolitics, Parapolitics, Metapolitics," 80.

90 Bosteels, "Archipolitics, Parapolitics, Metapolitics," 92.

91 See Lampert, "Jacques Rancière and the Politics of Theory."

92 Jacques Rancière, “On the Theory of Ideology-Althusser's Politics,” 134.

93 Horkheimer, "Traditional and Critical Theory," 216.

94 Donald Reid, “Introduction to Jacques Rancière," in Proletarian Nights, xxxiv.

95 Horkheimer, "The State of Contemporary Social Philosophy and the Tasks of an Institute for Social Research," 32.

96 Celikates, Critique as Social Practice, 3.

97 Finlayson, "The Question of Praxis in Adorno's Critical Theory," 61.

98 Theodor W. Adorno, "Marginalia to Theory and Practice," in Critical Models: Interventions and Catchwords, trans. Henry W. Pickford (New York: Columbia University Press, 2005), 269.

99 Finlayson, "The Question of Praxis in Adorno's Critical Theory," 63.

100 See Matthew Lampert, "Beyond the Politics of Reception: Jacques Rancière and the Politics of Art," Continental Philosophy Review 50, no. 2 (2017), esp. pp. 183185.

101 Alain Badiou, "Rancière and the Community of Equals," in Metapolitics, trans. by Jason Barker (New York: Verso, 2011), 111.

102 Paul Feyerabend, Against Method (New York: Verso, 1993), 216. 